\title{
CURRENT STATUS OF FUNCTIONAL FOODS RESEARCH AND DEVELOPMENT IN INDONESIA: OPPORTUNITIES AND CHALLENGES
}

\author{
[Tren Penelitian dan Pengembangan Pangan Fungsional di Indonesia: \\ Peluang dan Tantangan]
}

\author{
Indah Purwaningsih ${ }^{1) \star}$, Ria Hardiyati ${ }^{1)}$, Muhammad Zulhamdani ${ }^{2)}$, Chichi Shintia Laksani ${ }^{2)}$, \\ and Yan Rianto ${ }^{2)}$ \\ ${ }^{1)}$ Research Centre for Science, Technology and Innovation Policy and Management, Indonesian Institute of Sciences (LIPI), Jakarta \\ ${ }^{2)}$ Center for Implementation and Innovation of Science and Technology, Indonesian Institute of Sciences (LIPI), Jakarta
}

Received May $8^{\text {th }} 2020$ / Accepted March $23^{\text {rd }} 2021$

\begin{abstract}
The development of functional foods requires extensive research and development (R\&D) activities for product development, technology development and commercialization. However, it becomes rather a complex issue in developing countries, including Indonesia. This study briefly discusses the status of functional foods R\&D in Indonesia by understanding the opportunities and challenges. Employing scientometrics with bibliometric data from Scopus Database from the early retrievable date to October 29, 2018, the study finds out that R\&D on functional foods in Indonesia indicates a substantially increasing trend in the last decade. The research activities are mostly conducted by public research institutes (PRIs) and universities in the area of identification of bioactive compounds and their effects on health. They explore the abundant potentially indigenous biodiversity from Indonesia, both land and marine resources. Nonetheless, the R\&D activities are still lacking of network and integration between the subject areas. Underdeveloped infrastructure, limited human resources and financial support, costly preparation for the clinical test to satisfy health claims regulation and the gap between academic research and industry have been key issues in Indonesian functional foods $R \& D$. By using innovation system perspectives, this study suggests that public R\&D on functional foods demands active collaboration between PRIs, universities and industry as well as the supportive regulation system from policymakers to enhance the development of functional foods in the future.
\end{abstract}

Keywords: collaboration partnership, functional foods, Indonesia, innovation system, research and development

\begin{abstract}
ABSTRAK
Pengembangan pangan fungsional membutuhkan dukungan riset yang bersifat ekstensif, mulai dari pengembangan produk, teknologi dan pemasaran. Hal ini menjadi permasalahan yang kompleks untuk negara-negara berkembang, termasuk Indonesia. Penelitian ini menggunakan analisis saintometrika dengan data bibliometric dari Scopus Database terkait penelitian dan pengembangan pangan fungsional di Indonesia sejak data pertama sampai dengan 29 Oktober 2018. Penelitian menemukan bahwa pada dekade terakhir intensitas penelitian di area pangan fungsional di Indonesia mengalami kenaikan yang signifikan. Pelaku kegiatan penelitian tersebut didominasi oleh lembaga penelitian dan pengembangan (litbang) pemerintah dan perguruan tinggi. Fokus area penelitian di antaranya identifikasi komponen bioaktif dan efeknya terhadap kesehatan melalui eksplorasi kekekayaan biodiversitas. Fragmentasi jejaring penelitian, keterbatasan pembiayaan, infrastruktur, sumber daya manusia, besarnya biaya uji klinis dan gap antara akademia-industri masih menjadi kendala. Dalam perspektif sistem inovasi, riset yang dilakukan lembaga litbang pemerintah memerlukan partisipasi aktif dan kolaborasi antara lembaga riset pemerintah, peruruan tinggi, dan industri, serta dukungan kebijakan dari pemerintah untuk dapat mendukung pengembangan pangan fungsional di masa depan.
\end{abstract}

Kata kunci: Indonesia, kemitraan, pangan fungsional, penelitian dan pengembangan, sistem inovasi

\footnotetext{
The manuscript has been presented in The $16^{\text {th }}$ Asean Food Conference 2019, October $15^{\text {th }}-18^{\text {th }} 2019$, Bali-Indonesia
} ${ }^{*}$ Corresponding Author: E-mail: inda012@lipi.go.id 


\section{INTRODUCTION}

The development of functional food industry has shown a considerably growing trend recently. Based on Statista (2020), the global market size of functional foods generated revenue of around $\$ 247.89$ billion in 2017 and it was projected to reach $\$ 319.93$ billion by 2022 .

Some factors have contributed to the increasing demand for functional foods in many parts of the world. Nowadays, people pay more attention to foods with functional benefit to their health (KüsterBoluda and Vidal-Capilla, 2017; Ozen et al., 2012) rather than that to satisfy hunger only (Bigliardi and Galati, 2013). People demand foods to support health and wellbeing as part of their dietary habits (Iwatani and Yamamoto, 2019). Functional food is expected to improve life quality for the elderly population as well as to increase life expectancy. Another importance is that functional foods might offer a preventive solution over the increasing health costs. Also, the advances of science and technology in the food industry have contributed to functional food novelty (Bigliardi and Galati, 2013).

The concept of functional foods was first introduced in the 1980s by the Japanese government through the initiation of a national functional food research program (Bigliardi and Galati, 2013; Shimizu, 2012). The research program was as an effort to respond to the increasingly expensive health costs. The scientists and researchers proposed that besides providing primary nutrients, there exists the tertiary physiological function of foods to promote health and to reduce the risks of diseases (Nazir et al., 2019). The Japanese Government began implementing food categorization with certain health functions, Food for Specified Health Use, (FOSHU) in 1991 (Shimizu, 2012). The demand for functional food eventually grew steeply in Japan from 1997-2007 (Iwatani and Yamamoto, 2019).

Offering health and economic value at the same time (Nazir et al., 2019), the development of functional foods industry might open opportunities for developing countries. Some developing countries, including Indonesia, endowed with abundant biodiversity and indigenous knowledge of health effect of any particular plants (von Rintelen et al., 2017) and spices (Viuda-Martos et al., 2011). Indonesia's big population might generate market and labor productivity. Also, functional foods may support the improvement in dietary practices of people's daily life (Wagner and Brath, 2012). The improvement of these dietary practices can be a preventive solution in response to the alarming prevalence of noncommunicable diseases in Indonesia. The prevalence of diabetes mellitus, hypertension, and cancer in 2018 reached to 2.0, 8.4 and $1.8 \%$ respectively (Badan Penelitian dan Pengembanan
Kesehatan Kementerian Kesehatan, 2018). This concern on the importance of functional foods development has attracted the Indonesian Society for Functional Food and Nutraceutical together with academicians, researchers, industry and the government to define functional foods term in Indonesia. Functional foods comprise either fresh or processed food containing components with physiological improvement functions and/or those with disease risk reduction functions; these claims should be supported by scientific evidences; and it should be consumed as normally as part of the daily habit (Amaliah et al., 2019). This definition could guide the development of functional foods in Indonesia for both academic area and industry.

However, extensive R\&D is required for the development of functional foods (Nazir et al., 2019). The R\&D activity involves identification of bioactive compounds, assessment of physiological effect, product formulation and processing, and preparation for the clinical test to satisfy the regulatory demand. These research activities will provide scientific evidence to prove food functionality (Betoret et al., 2011). The R\&D on functional foods is also as substantial as to obtain innovatively functional products to meet the existing demand of consumers (Betoret et al., 2011).

Nonetheless, complexity and uncertainty might characterize R\&D on functional foods. The resource intensive activity in basic research and technology development is both costly and time consuming. So is the preparation to fulfil the regulatory requirements for health claim and commercialization. These systemic failures demand several partnership schemes to support the development of functional food industry (Moors, 2012).

This paper aims to discuss the status of $R \& D$ on functional food in Indonesia to identify how $R \& D$ could promote functional foods development in Indonesia, including the industry, by understanding the opportunities and challenges.

\section{MATERIALS AND METHODS}

\section{Materials}

This study employed both primary and secondary data. Primary data is bibliometric data of scholarly output on functional foods R\&D in Indonesia from Scopus Database between 1966 2018 and the results of deep interview and focussed group discussion (FGD) related to the status of R\&D on functional foods in Indonesia, the opportunities and challenges. The secondary data is information from research paper, newspapers and government regulation on functional foods development. 


\section{Methods}

This study was conducted in 2018-2019. It employed mixed methods by combining the use of quantitative and qualitative methods. These methods were conducted sequentially by putting quantitative inquiry first and followed by qualitative inquiry to get a more robust analysis (Oddbjørn, 2019). Quantitative inquiry was applied through scientometrics to examine the scientific publication trend on functional foods R\&D in Indonesia. Qualitative inquiry was conducted through deep interview and FGD to support and supplement the first findings.

Mulchenko defines scientometrics as "a quantitative study of the research on the development of science". Scientometrics is also considered as a technique that includes measuring research impact and mapping the knowledge structure, and evolutions in a domain based on the large-scale scholarly data set (Zhong et al., 2019). The evaluation of such bibliometric data of scholarly output that uses the scientometrics, can help us understand the ongoing and latest research trend and progress. One of the techniques in scientometrics to map the knowledge structure is co-word analysis.

Firstly, the literature review was used to find keywords on functional foods R\&D in Indonesia. The keywords were discussed in the first FGD in September 2018 with 3 experts on functional foods from both universities and public research institutes (PRIs) and were finalized in the second FGD in October 2018 attended by 5 university experts. The final keywords were employed to search bibliometric data of scholarly output supported by Scopus Database.

Bibliometric data of scholarly output on functional foods R\&D in Indonesia were collected from Scopus Database from the earliest retrievable date to October $29^{\text {th }}, 2018$. The data collection used several keywords that describe functional food research in the "title", "abstract", and "keywords", as well as the word "Indonesia" in "affiliation country". Keywords related to definitions and concepts of functional foods $R \& D$, were the result of the first FGD. The syntax used in the advanced search menu is as follows: ((TITLE-ABS-KEY("functional beverage") OR TITLE-ABS-KEY("functional food") OR TITLE-ABS-KEY("functional drink")) AND AFFILCOUNTRY(Indonesia)) OR ( TITLE-ABS-KEY ( "food" ) OR TITLE-ABS-KEY ( "bioactive com pound" ) AND ( TITLE-ABS-KEY ( "anti diabetic" ) OR TITLE-ABS-KEY ( "Antioxidant Activity" ) OR TITLE-ABS-KEY ( prebiotic) OR TITLE-ABS-KEY ( "anti aging" ) OR TITLE-ABS-KEY ( "anti cholesterol" ) OR TITLE-ABS-KEY ( "anti cancer") OR TITLE-ABS-KEY ( "Oxidative Stress" ) OR TITLEABS-KEY ( "antihypertensive" ) OR TITLE-ABSKEY ( "cardiovascular drug" ) OR TITLE-ABS-KEY
( "Antibacterial Activity" ) OR TITLE-ABS-KEY ( "anti diarhea" ) OR TITLE-ABS-KEY ( "immunology" ) OR TITLE-ABS-KEY ( probiotic ) OR TITLEABS-KEY ( "anti obesity" ) OR TITLE-ABS-KEY ("non communicable disease") OR TITLE-ABSKEY ("anti allergic")) AND AFFILCOUNTRY (indonesia )). There are 439 scientific publications on functional food in Indonesia during the period of 1996-2018 comprising 334 journals, 95 conference proceedings, 7 books and 3 book series. These bibliometrics data can help examine the research trend and progress.

Furthermore, VOSviewer (Version 1.6.14) was used for co-word analysis in this paper. VOSviewer (Version 1.6.5) is a free bibliometric network analysis tool that was chosen for its collaboration network visualization and text mining functionality (Yu and Hayes, 2018). The network from VOSviewer can help discover the implications hidden in a considerable amount of information, one of them is to find the relation which exists between raw material, bioactive compound, and plausibly physiological effect.

To clarify the first findings and to explore specific condition, individual deep interviews were held with some stakeholders who were involved in the value chain of functional foods development. Deep interviews with experts and researchers from universities (10) and PRIs (15) aimed to understand the R\&D activities on functional foods, the opportunities and constraints. Interviews with government officials from PRIs (directors) were conducted with the intention of getting data regarding the research roadmap on the development of functional foods in Indonesia. Other targets of the interview were those from industry, comprising 3 big local companies and 3 small and medium enterprises (SMEs) that produced functional food products. The interviews aimed to explore the economic opportunity of the functional foods through the firms' experiences and perspectives as well as their technological capacity in product development. The other interview was with government officials from the National Agency of Drug and Food Control of the Republic of Indonesia (BPOM) to understand the government policies on foods labelling and functional foods claims.

The collected data were analyzed and triangulated in order to get data validity and reliability. The final confirmatory FGD was held in December 2019 involving 8 participants who represented related stakeholders (2 experts, 2 government bureaucrats from PRI and BPOM, 1 big industry, 1 SME and 2 researchers). This FGD aimed to confirm the findings and to draw recommendation for functional foods development in the future. 


\section{RESULTS AND DISCUSSION}

\section{Trend of functional foods $R \& D$ in Indonesia}

The R\&D on functional foods in Indonesia is growing. The bibliometrics data of scholarly outputs from Scopus Database indicated the research activities on functional foods began in 1996. There are 439 scientific publications on functional food in Indonesia between 1996-2018. The steep increase in 2011 (Figure 1) might indicate that $R \& D$ activity on functional food in Indonesia was getting more intensive.

The intensive research and development activities on functional food in the period of 19962018 cover several subject areas (Figure 2). Most of the research activities work on the area of basic research, indicated by the dominated keywords of "effect", "extract", "addition", "application", "identification", "isolation", and "characterization". Only a few researches have reached development stages, clinical test and commercialization, which is indicated by smaller keywords of "food processing", "human", and "production". Moreover, the result of the co-word analysis shows a few networks between keywords (Figure 2). This condition might signify that R\&D on functional foods in Indonesia is still fragmented between subject areas.

Nonetheless, some government policies are indicated to have contributed to the rise of $R \& D$ on functional foods in Indonesia in 2011. The Indonesian Government launched a program on food and nutrition development as part of the national priority for the National Medium Development Plan 2010-2014 to improve health status of the people. At the same time, the government also prepared the National and Regional Action Plans for Foods and Nutrition in 2011 to strengthen the development of health status programs; one of which is through intensifying R\&D activity on foods and nutrition. The other policy that might trigger the development of $R \& D$ on functional foods in Indonesia is the regulation on claim and labelling on processed foods in 2011. The National Agency of Drug and Food Control of the Republic of Indonesia, who responsible for drug and food assess-ment, is authorized for the regulation on health claim and labelling. Based on Head of BPOM Regulation HK.03.1.23.11.11.09909/2011, functional foods are foods with health-related claims: nutrition claim and health claim (nutritional function claims, other claims, and disease-risk reduction claims). Scientific evidence is obliged to prove the functionality of the product to propose these claims. Furthermore, food product should pass clinical test in order to obtain labelling permission for other claims and diseaserisk reduction claims. There is interconnection between these three government policies that has intention of improving health status of the people through nutrition enhancement. R\&D on functional foods becomes one of policy instruments to achieve the goal.

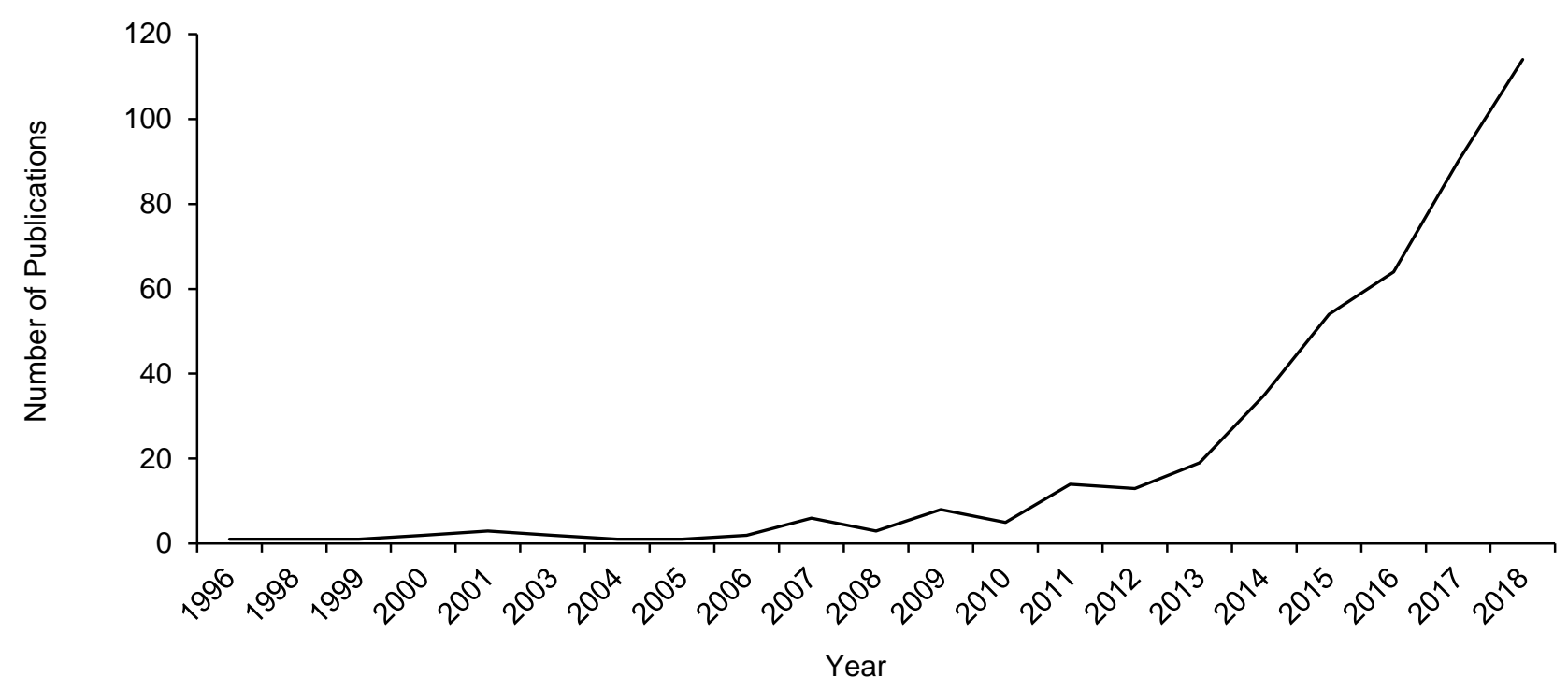

Figure 1. Trend on Functional Foods R\&D in Indonesia 1996-2018 based on Bibliometric Data in Scopus Database 


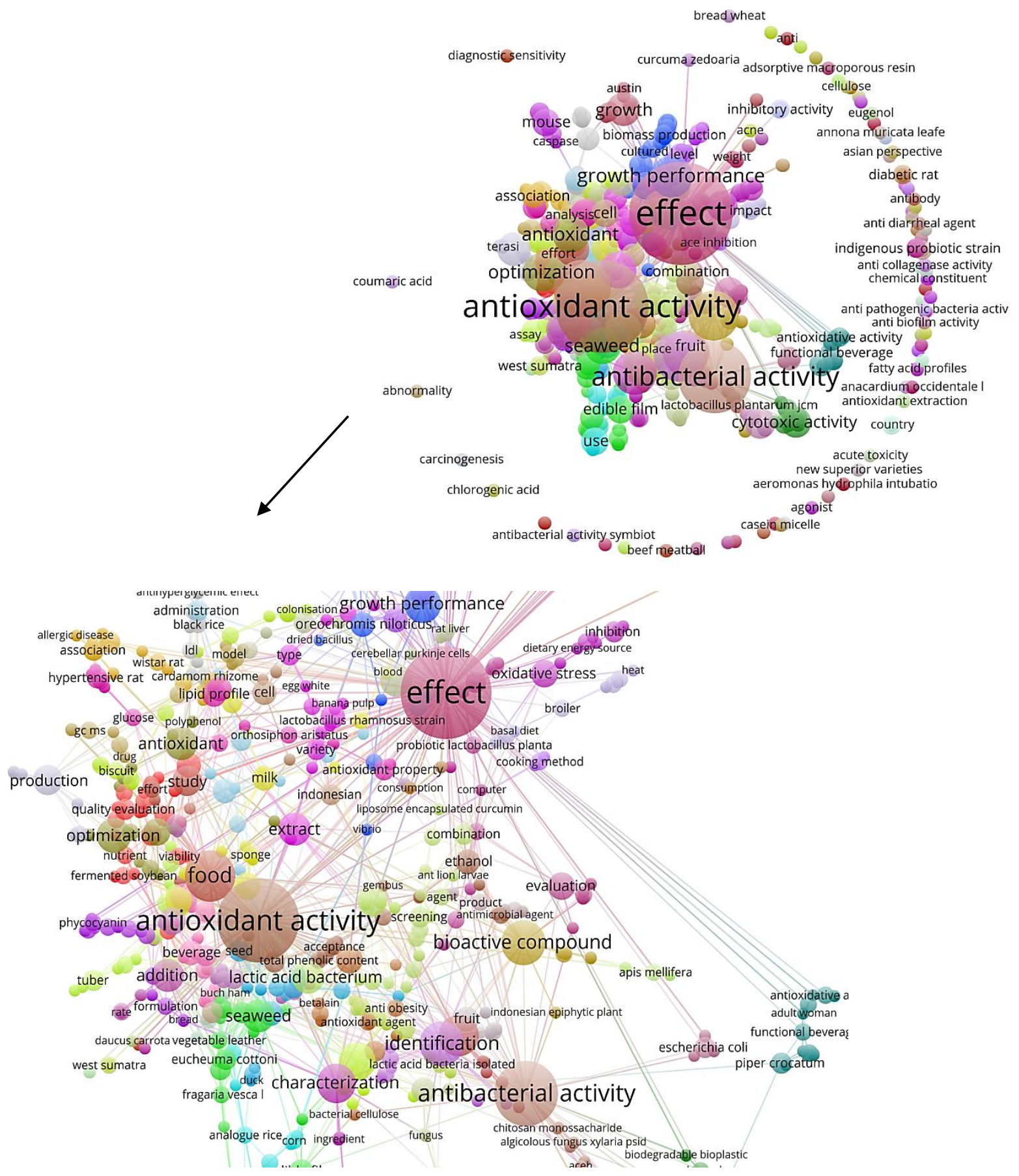

Figure 2. Co-word analysis of bibliometric data on functional foods in Indonesia based on title

\section{Potentials of biodiversity}

Indonesia is a tropical archipelago which is endowed with a huge biodiversity. Laying between Pacific Ocean and Indian Ocean, Indonesia is a habitat for $15.5 \%$ of the world flora and $10 \%$ of the world species comprising mammal, bird, reptile, fish, and butterfly species (Ministry of Environment and Forestry of Indonesia, 2014). In addition, mangrove, algae, sea grasses and other marine flora are also found in Indonesia waters. This wealth on biodi- versity is potential not only for agricultures (Ministry of Environment and Forestry of Indonesia, 2014), but also for pharmaceutical and biotechnology research and development. The indigenous medical plants in Indonesia rank the second highest after Amazon rain forest (von Rintelen et al., 2017).

The potentials of biodiversity have attracted research and development on functional foods in Indonesia. PRIs and universities as the main actor in Indonesian innovation system have conducted ex- 
ploration on Indonesian biodiversity to identify their potential bioactive compound. Most of the subject of exploration comprising not only flora, but also fauna and microbes inhabiting both land and waters. Macro algae and micro algae are considered as some of potential resources to be developed as functional food products. Besides its antioxidant activity benefits for anti-cancer, the availability of the resources is possibly high since Indonesia has a long coastline for growing macro and micro algae.

Based on co-word analysis of bibliometric data from Scopus Database, some indigenous resources have been researched for its plausible physiological benefits described in the following table (Table 1).

\section{Response to Health status of Indonesian society}

The development of R\&D on this area is as important as to provide an alternative solution to the increasing prevalence of non-communicable diseases and health cost in Indonesia. The prevalence of non-communicable disease in Indonesia is alarming in the recent years. Prevalence of obese increases from $13.6 \%$ in 2013 to $21.8 \%$ in 2018 . Similarly, the prevalence of diabetes mellitus and cancer rises in this five year as much as $1.5-2 \%$ and $1.4-1.8 \%$ in respective, while the prevalence of heart coronary remains 1.5\% (Badan Penelitian dan $\mathrm{Pe}$ ngembangan Kesehatan Kementerian Kesehatan, 2018). This condition indicates that there might be a problem with Indonesian people's either life style or daily diet. Most of the research findings (Table 1) have tried to identify the effect of bioactive compound in particular resources to address degenerative diseases, including anti-diabetic, anti-cancer, anti-hypertension, and cholesterol.

\section{Challenges of R\&D on functional foods in Indonesia}

PRIs and universities actively conducted research on functional foods in Indonesia, some of which do product development and try to reach industry for commercialization. There has been an apparent consensus among researchers on the potentials of the richness of Indonesian biodiversity and culinary. Hence, the research mostly based on using indigenous resources and traditional foods as the starting materials.

Nonetheless, limited funding and human resources, underdeveloped infrastructure, and the absence of research roadmap on functional foods are indicated to become barriers in Indonesia. Networks among researches have not been so well established that each research goes independently and reaches a similar stage. Consequently, most of the research ends at the stage of identifying bioactive compounds and its possible effect on health.
Without neglecting that identification and validation of particular markers and the potential health benefit is the key approach to functional foods R\&D, the research should be able to go further to development and innovation stages (Maestre et al., 2017).

Clinical trial is another step R\&D on functional foods should take when the product is going to be commercialized (Brown et al., 2018). Clinical trial is required in order to prove the effectiveness of food's claim and to assure human safety. However, a few government labs in Indonesia, both PRIs and universities, have passed clinical test for functional food products due to a long and costly procedures.

Furthermore, research network on functional foods development in Indonesia is still weak. The absence of national roadmap might lead to disintegration of R\&D on functional food. Each institution might do research and functional food product development based on their preference. Linkage among institution has not been established. This fragmentation is also signified by the result of coword analysis (Figure 2).

Besides basic research, PRIs and universities conduct product development and commercialization as well. Unfortunately, it is not easy to reach industry for commercialization. Functional foods industry in Indonesia is still dominated by big companies, both local and multinational companies, such as dairy products and baby foods. Introducing new products to these big companies is not as easy as they have already created their market. Uncertainty might be another reason before accepting new products from government labs. Also, companies producing functional food products have already developed their own $R \& D$ unit since this industry demand knowledge and research-intensive capacity.

On the other hand, some PRIs and universities have successfully assisted SMEs by doing product development assistance. These SMEs are still on effort in creating market. They are still lack on research capacity, infrastructure, funding and knowledge on regulation. Product development are conducted through empowering society to produce and to market functional food products developed by the PRIs and universities. Assistance was also given in the form of introducing particular technology to add the product value, i.e. fortification and natural preservatives for traditional culinary. Mostly, this scheme is initially funded by the government to improve the economic status of the people in a particular region through exploring its potential resources. However, due to limited knowledge and resources to satisfy the regulation, most of the food products could not afford claims label from BPOM. 
Table 1. Potentials of Indonesia's indigenous biodiversity for functional foods based on publication data

\begin{tabular}{|c|c|c|}
\hline Raw Materials & Bioactive Compound & Plausibly Physiological Effect \\
\hline Red ginger & Antioxidant & \\
\hline Ginger & Antioxidant & Cholesterol \\
\hline Curcuma xanthorrhiza & Anti biofilm activity & \\
\hline Garcinia mangostana & Antioxidant & \\
\hline Aloe vera var & Antioxidant & \\
\hline Marine bacterium & Antioxidant & Anti cancer agent \\
\hline Sea cucumber & Antioxidant & Anti cancer \\
\hline Sponge jaspis & Antioxidant & Anti cancer \\
\hline Stichopus variegatus (teripang) & Antioxidant & Anti cancer \\
\hline Lactobacillus plantarum pentosus & Antioxidant & Anti cancer \\
\hline Marine endophitic bacterium & Antioxidant & Anti cancer \\
\hline Macroalgae & Antioxidant & Anti cancer \\
\hline Seaweed & Antioxidant & Anti cancer, anti diabetic \\
\hline Green cincau & Antioxidant & Anti cancer \\
\hline Soursop leaf & Antioxidant & Anti cancer \\
\hline Fermented goat milk & Antioxidant & \\
\hline Cajanus cajan/pigeon pea/Gude & & Antidiabetic activity \\
\hline Sponge & Antioxidant, antibacterial activity & Anti diabetic, anti cancer \\
\hline Cinnamomum burmannii & Antioxidant & Anti diabetic; anti obesity \\
\hline Piper crocatum & Cytotoxic activity & Anti diabetic \\
\hline Young mangrove rhizophora mucronata & & Anti diabetic \\
\hline Java tea & Antihyperglycemic activity & Anti diabetic \\
\hline Orthosiphon aristatus & Antioxidant, antihyperglycemic activity & Anti diabetic \\
\hline Kidney bean flour & Hypoglycemic & Anti diabetic \\
\hline Urena lobata leaf & & Anti diabetic \\
\hline Taro & & Anti diabetic \\
\hline Amomum cardamomum wild (kapulaga) & & Anti inflammatory \\
\hline Cardamom rhizome & & Anti inflammatory \\
\hline Clerodendrum paniculatum (pagoda flower) & & Anti inflammatory \\
\hline Pagoda leafe & & Anti inflammatory \\
\hline Sargassum plagyophyllum & & Anti collagenase \\
\hline Mangrove avicennia marina & Antioxidant, antibacterial & Anti diabetic \\
\hline Black soybean & Antioxidant & \\
\hline Indonesian cashew & & Antihypertension \\
\hline Black rice & Antihyperglycemic effect, antioxidant & Anti diabetic \\
\hline Rambutan & & Anti obesity \\
\hline Red dragon fruit & Antioxidant & \\
\hline Archidendron bubalinum & Antioxidant & \\
\hline Archidendron pauciflorum (jengkol) & Antioxidant & \\
\hline Bambusa vulgaris (bamboo) & Antioxidant & \\
\hline Binahong leaf & Antioxidant & \\
\hline Bitter melon & Antioxidant & \\
\hline Black mulberry leaf & Antioxidant & \\
\hline Bruguiera gymnorrhiza (putut) & Antioxidant & \\
\hline Cacao & Antioxidant & \\
\hline Candi banana & Antioxidant & \\
\hline Daucus carrota & Antioxidant & \\
\hline Broccoli & Antioxidant & \\
\hline Fragaria vescaf & Antioxidant & \\
\hline Jamblang & Antioxidant & \\
\hline Kolang kaling & Antioxidant & \\
\hline Mangifera indica (mango) & Antioxidant & \\
\hline Morus nigra (black murbey) & Antioxidant & \\
\hline Robusta coffee bean & Antioxidant & \\
\hline Lemongrass & Antioxidant & \\
\hline White turmeric & Antioxidant & \\
\hline Jack bean & Antioxidant & \\
\hline Arrowroot & Hypoglycemic effect & Anti diabetic \\
\hline Cassava & Hypoglycemic effect, gluten free & Anti diabetic \\
\hline & Antioxidant, anti bacterial activity, & \\
\hline Banana & dietary fiber & \\
\hline
\end{tabular}


The Indonesian Government regulations on functional foods have undergone several amendments. Based on Head of BPOM Regulation 13/2016 on claims and labelling (2016), healthrelated claims include (1) nutrition claims, (2) health claims and (3) isotonic claims, no added sugar claims, lactose claims, and gluten claims. Nutrition claims include nutritional content claims and nutritional comparison claims, while health claims include nutritional function claims, other claims (fiber), and disease-risks reduction claims. Each claim requires different standard and procedures to obtain claim permission. In order to obtain diseaserisks reduction claims, products should follow clinical test to prove the safety on human use. Researchers in both PRIs and universities have to understand the regulation since they are doing research and product development in which the results should meet the government standard before being launched to market.

\section{Partnership on functional foods development}

R\&D on functional foods in Indonesia demands an integral support from the whole innovation system. Neither PRIs nor universities may carry out the design of functional foods $R \& D$ individually. Policy makers can draw a grand design on functional foods R\&D covering the whole stages and involved actors. Integration among research activities might refocus and make the consensus on the definition and target of the functional food R\&D in Indonesia. Integration might also solve the barriers of limited public labs' infrastructure, human resources and financial support, which in turn might lead to advancement of the research results. In this case, government's incentive is substantial with the intention to improve the capacity of public re-search infrastructure and the researchers.

Furthermore, future advances on this area needs understanding from and eventually are potential for the development of academia, society, and industry (Moors, 2012). The success of functional foods market not only depend on an effective scientific research, but should be adequate with consumers (Gok and Ulu, 2018; Guiné et al., 2020). Developing academia-industry linkage might be an alternative. The innovation process of functional foods demands interplay of various actors, including public-private partnership (Moors, 2012). The successful innovation of functional foods requires creative management that encompasses entrepreneurial (Mark-Herbert, 2004) and strategic planning perspectives through collaboration and partnership (Khan et al., 2013; Mark-Herbert, 2004).

Collaboration and partnership on functional foods development might take different scheme depending on the target of the research results and the industry's scale. On one hand, collaboration for product development might be sufficient for assisting SMEs. On the other hand, PRIs can either promote their patented technology for big companies or do collaborative basic research. Collaboration might also in the form of resource sharing (Bin et al., 2013; Moors, 2012). PRIs and universities as the knowledge pool can use resource sharing mechanism to support functional foods industry by providing research infrastructure and man power. Moreover, partnership can support the industry through data sharing to provide scientific evidence for claims registration.

\section{CONCLUSION}

Research and development on functional foods in Indonesia is growing. Exploring the richness of biodiversity and traditional foods of Indonesia, PRIs and universities are the main actor on these functional foods R\&D activities. Despite a steep increase on the R\&D intensity in recent years, complexity still become barriers. The main challenges of $R \& D$ on this area are not limited to funding, underdeveloped infrastructure, and the gap between academiaindustry, but also the efforts for claims compliance. The development of functional foods demands collaboration and partnership from the whole actors involved in the innovation system. Government might support by providing incentives for the development of research infrastructure and man power of PRIs and universities. These resources pool eventually might conduct collaboration and partnership with industry through resource sharing, product development and technology licensing depending on the industry's scale and needs.

\section{ACKNOWLEDGEMENT}

The authors would like to express gratitude to the Ministry of Science, Technology and Higher Education, Republic of Indonesia who provides the research grant of National Research Incentives (Insinas) and the Indonesian Institute of Sciences (LIPI), for the support throughout the flagship research program on the development of functional foods in Indonesia.

\section{REFERENCES}

Amaliah I, David W, Ardiansyah A. 2019. Perception of millennial generation toward functional food in indonesia. J Funct Food Nutraceutical 1: 3140. DOI: 10.33555/fffn.v1i1.11.

Badan Penelitian dan Pengembanan Kesehatan Kementerian Kesehatan. 2018. Hasil utama 
riskesdas 2018. In hasil utama riskesdas tentang prevalensi diabetes melitus di Indonesia 2018.

Betoret E, Betoret N, Vidal D, Fito P. 2011. Functional foods development: Trends and technologies. Trends Food Sci Tech 22: 498508. DOI: 10.1016/j.tifs.2011.05.004.

Bigliardi B, Galati F. 2013. Innovation trends in the food industry: The case of functional foods. Trends Food Sci Tech 31: 118-129. DOI: 10.1016/j.tifs.2013.03.006.

Bin A, Gianoni C, Mendes PJV, Rio C, Salles-Filho SLM, Capanema LM. 2013. Organization of research and innovation: a comparative study of public agricultural research institutions. J Technol Manage Innov 8: 209-218. DOI: 10.4067/s0718-27242013000300048.

Brown L, Caligiuri SPB, Brown D, Pierce GN. 2018. Clinical trials using functional foods provide unique challenges. J Funct Food 45: 233-238. DOI: 10.1016/j.jff.2018.01.024.

Gok I, Ulu EK. 2018. Functional foods in Turkey: marketing, consumer awareness and regulatory aspects. Nutr Food Sci 49: 668-686. DOI: 10.1108/nfs-07-2018-0198.

Guiné RPF, Florença SG, Barroca MJ, Anjos O. 2020. The link between the consumer and the innovations in food product development. Foods 9: 3-5. DOI: 10.3390/foods9091317.

Iwatani S, Yamamoto N. 2019. Functional food products in Japan - a review. Food Sci Hum Wellness 8: 96-101. DOI: 10.1016/j.fshw.2019. 03.011 .

Khan RS, Grigor J, Winger R, Win A. 2013. Functional food product developmentopportunities and challenges for food manufacturers. Trends Food Sci Tech 30: 27-37. DOI: 10.1016/j.tifs.2012.11.004.

Küster-Boluda I, Vidal-Capilla I. 2017. Consumer attitudes in the election of functional foods. Span J Market-ESIC 21: 65-79. DOI: 10.1016/j. sjme.2017.05.002.

Maestre M, Poole N, Henson S. 2017. Assessing food value chain pathways, linkages and impacts for better nutrition of vulnerable groups. Food Policy 68: 31-39. DOI: 10.1016/j.foodpol. 2016.12.007

Mark-Herbert C. 2004. Innovation of a new product category-functional foods. Technovation 24 713-719. DOI: 10.1016/s0166-4972(02)001311.

Ministry of Environment and Forestry of Indonesia. 2014. The fifth national report of Indonesia to the convention on biological diversity. Deputy minister of environmental degradation control and climate change ministry of environment and forestry. https://www.cbd.int/doc/world/id/ id-nr-05-en.pdf [June $26^{\text {th }} 2019$ ].

Moors EHM. 2012. Functional foods: Regulation and innovations in the EU. Innovation: The European J Soc Sci Res 25: 424-440. DOI: 10.1080/13511610.2012.726407.

Nazir M, Arif S, Khan RS, Nazir W, Khalid N, Maqsood S. 2019. Opportunities and challenges for functional and medicinal beverages: current and future trends. Trends Food Sci Tech 88: 513-526. DOI: 10.1016/j.tifs.2019. 04.011.

Oddbjørn B. 2019. Designing social science research. 146-150. Springer Nature, Switzerland. DOI: 10.1007/978-3-030-03979-0.

Ozen AE, Pons A, Tur JA. 2012. Worldwide consumption of functional foods: A systematic review. Nutr Rev 70: 472-481. DOI: 10.1111/ j.1753-4887.2012.00492.x.

Shimizu M. 2012. Functional food in japan: current status and future of gut-modulating food. J Food Drug Anal 20: 213-216. DOI: 10.38212/ 2224-6614.2093.

Statista. 2020. Global functional food market revenue 2013 \& 2022. https://www.statista. com/statistics/252803/global-functional-food-sa les/ [June $\left.7^{\text {th }} 2021\right]$.

Viuda-Martos M, Ruiz-Navajas Y, Fernández-López J, Pérez-Álvarez JA. 2011. Spices as functional foods. Crit Rev Food Sci 51: 13-28. DOI: 10.1080/10408390903044271.

Von Rintelen K, Arida E, Häuser C. 2017. A review of biodiversity-related issues and challenges in megadiverse Indonesia and other southeast asian countries. Res Ideas Out-Comes 3: e20860. DOI: 10.3897/rio.3. e20860.

Wagner $\mathrm{KH}$, Brath H. 2012. A global view on the development of non communicable diseases. Preventive Medicine 54: s38-s41. DOI: 10.101 6/j.ypmed.2011.11.012

Yu F, Hayes BE. 2018. Applying data analytics and visualization to assessing the research impact of the cancer cell biology (CCB) Program at the University of North Carolina at Chapel Hill. J eScience Librarian-ship 7: e1123. DOI: 10.7191/jeslib.2018.1123.

Zhong B, Wu H, Li H, Sepasgozar S, Luo H, He L. 2019. A scientometric analysis and critical review of construction related ontology research. Automat Constr 101: 17-31. DOI: 10.1016/j.autcon.2018.12.013. 